JOURNAL OF SECURITY AND SUSTAINABILITY ISSUES

ISSN 2029-7017 print/ISSN 2029-7025 online

2018 December Volume 8 Number 2

http://doi.org/10.9770/jssi.2018.8.2(7)

Scopus

\title{
TRENDS IN ECONOMIC AND SOCIAL SECURITY AT NATIONAL AND EUROPEAN LEVEL: INTERRELATIONSHIPS, THREATS AND OPPORTUNITIES
}

\author{
Nataliia Stukalo', Iryna Steblianko², \\ Anastasiia Simakhova ${ }^{3}$, Vadym Doroshkevych ${ }^{4}$ \\ ${ }^{1,2,3,4}$ Oles Honchar Dnipro National University, Gagarina Str. 72, Dnipro, 49000, Ukraine \\ E-mails: 'nstukalo@ukr.net ; ${ }^{2}$ irinasteb23@gmail.com, ${ }^{3}$ simakhova_a@fme.dnulive.dp.ua,40003997@gmail.com
}

Received 20 February 2018; accepted 10 October, published 30 December 2018

\begin{abstract}
The essence of economic and social security as a national and supranational category has been substantiated. The influence of political, economic and social factors on the condition of national and European security has been investigated. Priorities of the economic component of security have been defined: energy security, foreign trade and innovation-investment security, social security. The dialectical interrelationships of economic and social security have been established. The trends in economic and social security have been defined.
\end{abstract}

It is shown that social problems in the state are derived from the condition of its economic and political security. The main threats and opportunities of economic and social security at national and European level have been considered.

Keywords: European level, national, security, social and economic, trends, development.

Reference to this paper should be made as follows: Stukalo, N.; Steblianko, I.; Simakhova, A.; Doroshkevych, V. 2018. Trends in economic and social security at national and European level: interrelationships, threats and opportunities, Journal Security and Sustainability Issues, 8(2): 199-208. http://doi.org/10.9770/jssi.2018.8.2(7)

JEL Classifications: F15, F52, O11

\section{Introduction}

In scientific literature much has been written about such category as "security", its economic and social part and at other different levels (Stańczyk 2011; Teivāns-Treinovskis, Jefimovs 2012; Makštutis et al. 2012; Lankauskienė, Tvaronavičienė 2012; Kriviņš 2015; N̦esterova et al. 2015; Tumalavičius 2016; Tumalavicius 2017; Trofimovs, Ivančiks 2017; Menshikov et al. 2017; Načisčionis et al. 2018; Zahars, Stivrenieks 2018 and etc.). It's clear the national social and economic security influences international relations and business, international security and sustainability, foreign trade and investments, international migration and European stability significantly. It's worth to stress some trends in the social and economic security at national and European level. The aim of this article is to investigate the interrelations, threats and opportunities of trends in economic and social security. Actually there are a lot of them, especially when talking about national and European level of security and its development nowadays and in future. This article aims to identify the main threats and opportunities of economic and social security at national and European level.

The methodology of the article is generalization of the basis conditions of the theories of national security and security at the European market. The system analysis of the socio-economic security was performed, making it possible to identify the reasons of danger and threats at the beginning of their development and by the place 
where they arise, which is an important element of the mechanism of the state regulation.

The scientific novelty of the theoretical research lies in the substantiation of the interaction of the national and European levels of socio-economic security. The practical value of the findings of the article is related to the recommendations regarding the possibilities of modern tendencies of socio-economic security at the national and European levels.

\subsection{Literature review}

In the last century, different aspects of this problematic have been studied by many scholars all over the world. The influence of integration processes on European security in general is the main topic of works of such scholars G. Marks and M. R. Steenbergen (2004).

Security is one of the qualitative features of the society, the multi-faceted content of which is getting dynamically more complicated and depends on many factors that are changing in space and in time (Abramov, Moshinskij 2011; Ćábelková et al. 2015; Radwan 2018; Volchik et al. 2018; Tireuov et al. 2018; Todorov et al. 2018; Kuril 2018; Limba, Šidlauskas 2018; Brożyna et al. 2018; Tvaronavičienė 2018, Fakhry et al. 2018).

Today, the scientists and specialists that study the problems of economic security of the national economy are not unanimous when it comes to determining the essence of the basic concepts and principles of its regulation. Kozlovskyi et al. (2017) revealed the relationship between the economic stability of the national economy and economic security and investment, as well as made the corresponding forecasts based on the innovative approach, which is grounded on the economic-mathematical model of the organizational structure of management. The monograph of Dyson (2008) highlights the problems of europezation of the German political system, arguing that the political leaders have played the key role in launching the processes of the creation of the EU, and the Defense ministers used the "atlantization" and "europezation" in the interests of their national political tasks.

The category "social and economic security" is more completed. Some authors defined that social and economic security provides not only a country's sustainable economic development, but also its sense of population protection of vitally important interests of a society, country, and citizens, as well as national values and the way of living from external and internal threats (Smirnov et al., 2018; Komarova et al., 2018).

Economic security of the state should be considered as an institutional system of representing the conditions of the stable, resistant economic dynamics. In addition to institutional inertia, the property of the national economy is cumulativeness, which is determined by the capability to accumulate and concentrate hazards and threats, influencing one and the same "weak point" of the system (Steblianko, Doroshkevych 2017).

Hacker (2006) notes that under modern conditions, two greats foundations of economic security - a family and a working place - guarantee much less financial stability than they used to. Given the above, it is necessary to activate the action of the mechanisms of protection of medical aid, income security and pensions of the population. Bates (2017) reveals the causative relations between the powerful tension, prosperity and security. He argues that creation of the central hierarchy of the state is necessary in order to implement the tasks of the development, however, the way of using its power is also essential. The book of Kassab H. (2015) seeks to explain why weak states exist within the international system. Using the cases of Armenia, St. Kitts and Nevis, Lebanon, and Cambodia, the author argues that, if a state is weak and vulnerable, then it can practice an unexpected degree of relative autonomy unfettered by great powers.

There are different works about the issue of European energy security, because it is extremely relevant. It can be mentioned such researchers as Tvaronavičienė et.al. (2017), Prontera (2017) who study energy security, energy efficiency, and its relationship with economic development and stability in the country at European level.

Despite significant achievements of mentioned above authors, the issue of a comprehensive assessment of the 
economic and social impact of the national security policy on the European security remains open. One of the purposes of this article is to design the understanding of this problematic issue.

For deeper understanding, we should remind, that globalization and world's transformation into a single interrelated mechanism lead to the fact that the disintegration processes can be harmful not only to their neighbors and region but to the whole world. Thus, we would like to assess the economic and social security state at national and European level.

\section{Political, economic and social factors of national and European security}

Different political, social and economic factors influence national and European security. Priorities of the economic component of security are: energy security, foreign trade and innovation-investment security, social security.

The EU is an international system of the integrated type in the area of politics and economy and implies preservation of the state sovereignty of its member countries, but it has highly developed mechanisms of supernational regulation. They ensure vitality, reliability, effectiveness of internal and external processes, especially in the area of security and defense. The European Union, created as purely economic community, is built on the principles and values of the western civilization, is increasingly molded as a consolidated community with the features of the state organization with all appropriate attributes: common super-state structures, own currency, coordinated foreign policy, etc. Common foreign and security policy (CFSP, 2009) is one of the two intergovernment "pillars" of the EU, which set the goal to form a unified defense system.

According to the European statistics (Gas in Focus, 2017) Russia and Norway are the major natural gas supplier in the EU-28, moreover the share of Russia has increased in 2017 comparing to 2013 from $27 \%$ to $44 \%$. In 2014 it was $27 \%$, in 2015 it became $29,4 \%$ and in $2017-44 \%$ (Figure 1).

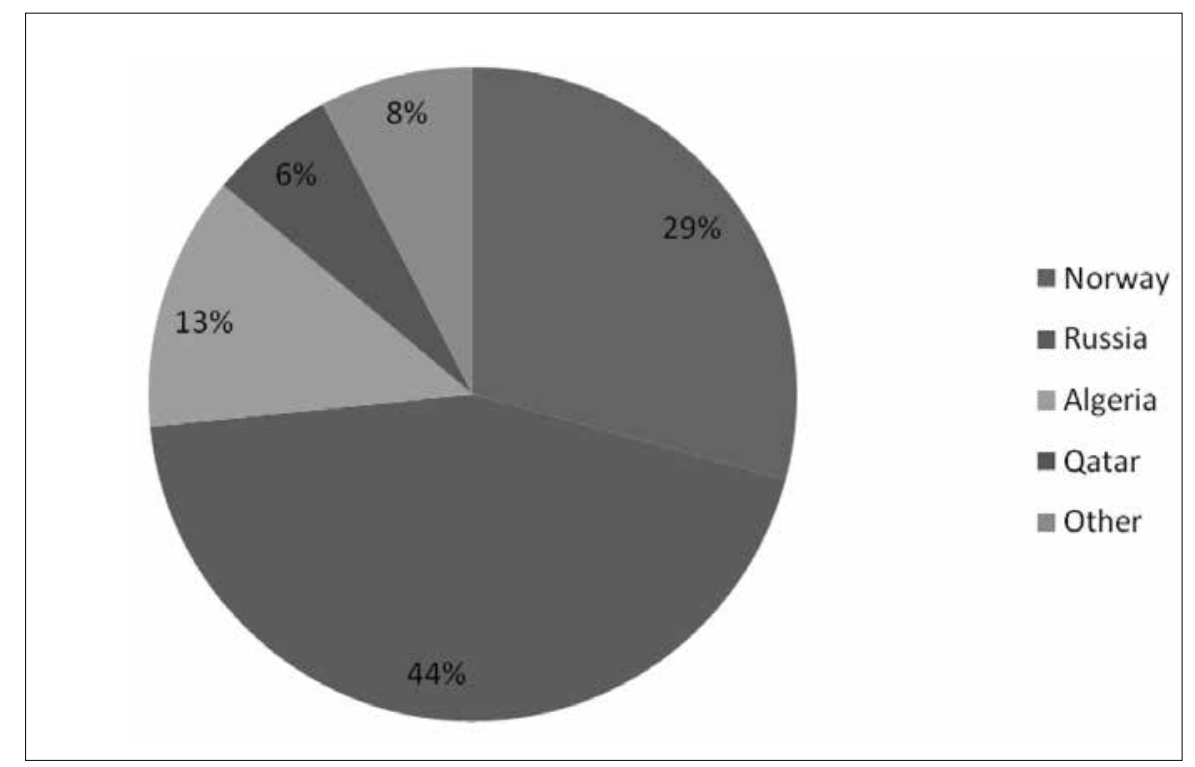

Fig. 1. Imports of natural gas in the EU-28, 2017

Source: Gas in Focus, 2017

From energy transit, to technology transfer, to investment protection, energy and trade present interplays across various fields. Improvements can be made to the EU trading system to ensure greater energy security and more efficient energy markets (Leal-Arcas, Rios, Grasso, 2015). The international community could create single energy markets at the regional level in different regions of the world (e.g. the internal energy market in the EU) and then connect the various regions (inter-regional connection of energy agreements). This entails the 
interconnection of grids and transit rules, which would provide energy security globally. Here is where the notion of energy TPNs (transnational policy networks) can play a major role moving forward, both for the EU's own energy networks and more generally energy networks around the globe.

\section{Interrelationships of economic and social security at national and European level}

According to Eurostat China, The USA, Switzerland and Russia are the major trade partners of the EU (Eurostat 2017) (Table 1).

Table 1. The EU-28 Trade in Goods by partners in 2016

\begin{tabular}{|l|c|l|c|}
\hline \multicolumn{1}{|c|}{ Top 10 partners in import } & Share of import, $\%$ & Top 10 partners in export & Share of export, $\%$ \\
\hline 1. China & 20.2 & 1. USA & 20.7 \\
\hline 2. USA & 14.5 & 2. China & 9.7 \\
\hline 3. Switzerland & 7.1 & 3. Switzerland & 8.2 \\
\hline 4. Russia & 7.0 & 4. Turkey & 4.5 \\
\hline 5. Turkey & 3.9 & 5. Russia & 4.1 \\
\hline 6. Japan & 3.9 & 6. Japan & 3.3 \\
\hline 7. Norway & 3.7 & 7. Norway & 2.8 \\
\hline 8. South Korea & 2.4 & 8. United Arab Emirates & 2.6 \\
\hline 9. India & 2.3 & 9. South Korea & 2.6 \\
\hline 10. Vietnam & 1.9 & 10. India & 2.2 \\
\hline
\end{tabular}

Source: Eurostat, 2017

It should be mentioned that EU is the main foreign trade partner for Ukraine. Nowadays more than $31 \%$ of Ukrainian trade is with the EU while $27 \%$ with Russia, $8 \%$ with China and $3 \%$ with the USA. So it is a perspective way for Ukraine to cooperate with EU in foreign activity.

European choice has influenced on Ukrainian business. Figure 2 represents the decrease of Ukrainian GDP (Gross Domestic Product) level, foreign direct investments (FDI) level and population real income level in 2014 and 2015. As suggest scientist (Collier 2007), in countries with economic decline is growing level of national security.

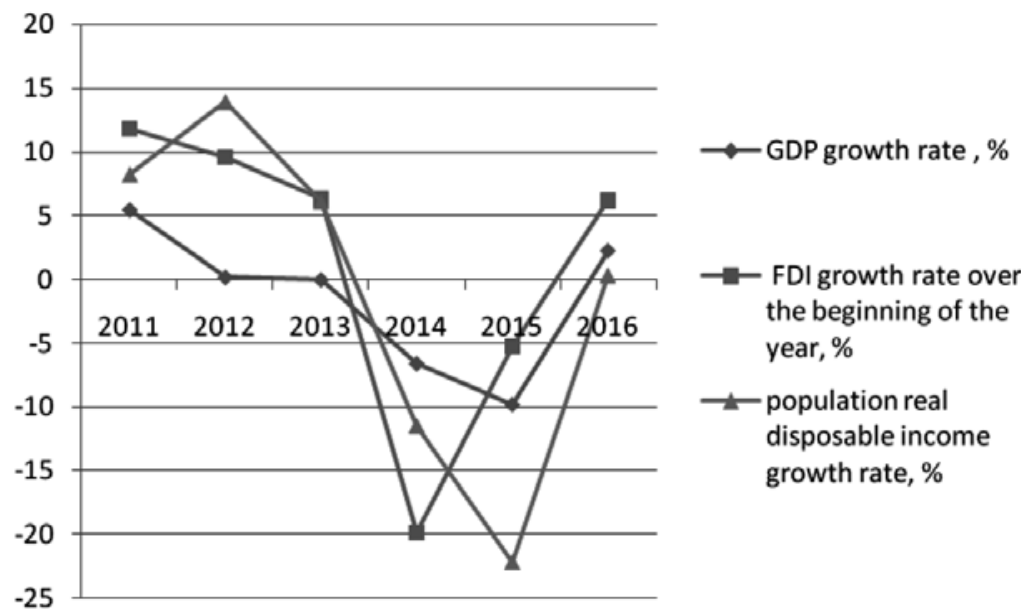

Fig. 2. Dynamics of Ukrainian economic indicators in 2011-2016 (per cent over the previous year, at the 2010 constant prices) 
Since 2014 changing of political course of Ukraine has caused reduction of economic indicators. It's not surprising, that Ukraine in 2014 and 2015 was not attractive for foreign investors and business partners, because of unstable situation, the threat of losing investments (Steblianko, Doroshkevych, 2017). Only in 2016 there were positive trends, when GDP, FDI and population income growth rate were $2.3 \%, 6.2 \%$ and $0.3 \%$. The highest GDP and FDI growth rate in the last 6 years was in $2011-5.5 \%$ and $11.8 \%$. Also figure 2 represents, that the FDI recovered in 2016 more than other indicator and had $6.2 \%$ growth. The main reason of such situation is Ukrainian government attempt to pursue democratic security politics to restore investor confidence and to enhance the international image of Ukraine. The worst economic indicators over the last 2 years were the population real disposable income level. In 2015 Ukrainians real income decreased by $22.2 \%$. This reduction caused poverty increasing, social tension and other economic problems in the country. In 2016 income level increased only $0.3 \%$.

Besides the economic consequences of the change of political course of Ukraine, there are also some important social consequences. Instability has negative influence on the level of national security (Menshikov et al. 2017). And it is natural that an effective social sphere cannot exist without a strong economic base (Simakhova 2016).

Today, the economy of Ukraine is in crisis due to reorientation from markets of the Commonwealth of Independent States to European markets. Major social challenges become: problem of employment, increase of wages, pensions and other social payments in conditions of depreciation of the national currency and high rates of inflation, achievement of European living standards of the population (Stukalo, Simakhova 2018).

Threats in national economic security led to migration of Ukrainian citizens to European countries. As for specific countries of migration, the Ukrainians in 2014-2016 have chosen Portugal, Czech Republic, Poland, Malta, Liechtenstein, Spain. Thus, the Ukrainians have applied asylum mainly in the South and Eastern European countries. The main reason of this fact, in our opinion, is the similar social and economic model of these countries with Ukrainian model. These countries, mainly also have transition social economy model (Stukalo, Simakhova 2018), like Ukraine has.

In general in EU there is critical situation with migrants. Since last several years their number has been increased. According to European statistics, in 2015, the EU countries with the largest number of migrants were Germany $(1,46 \mathrm{mln}$.), the UK (0,548 $\mathrm{mln}$.), Spain $(0,29 \mathrm{mln}$.) and Italy $(0,25 \mathrm{mln}$.) (Hawkins, 2017, p. 19).The number of people acquiring the citizenship of an EU Member State in 2015 was 841,2 thousand, among them 292,54 thousand migrants from 5 countries - Syria, Eritrea, Iraq, Afghanistan, Iran (Eurostat, 2017). So, all these countries are in crisis.

The material base for socio-economic safety is national wealth, which is accumulated by withdrawing a part of socially useful benefits in the form of taxes. That is why ensuring their coming in due quantity is the economic base of the existence of the state and the development of the country. The rules and regulations of the tax system determine the institutional reference points for the development of institutions in the area of economic safety. (Ball 2014).

Member countries of the EU in the process of the European economic integration faced the problem of the negative influence on economic safety, which causes complexity and specificity of tax systems of each country. On the one hand, unequal taxing creates the barriers for doing business on the inter-state scale, on the other hand, it leads to tax competition, and, therefore, creation of more beneficial taxation conditions, that grant greater security guarantees to the states - innovators. The member countries of the EU took decisive measures to make tax regulations closer and thus protected their economies from the deficits of fiscal revenues from the loss of capital, however, the tax legislation of these countries has not become fully unified yet. The efforts of the governments of the member countries of the EU have gradually led not only to the creation of the conditions of tax competition, but also have partially protected them from the influence of criminal schemes of shadow circulation, specifically in AVT, and have allowed decreasing smuggle delivery of excisable goods. 
The generalized scheme of interrelationships of economic and social security at national and European level has been represented at Figure 3.

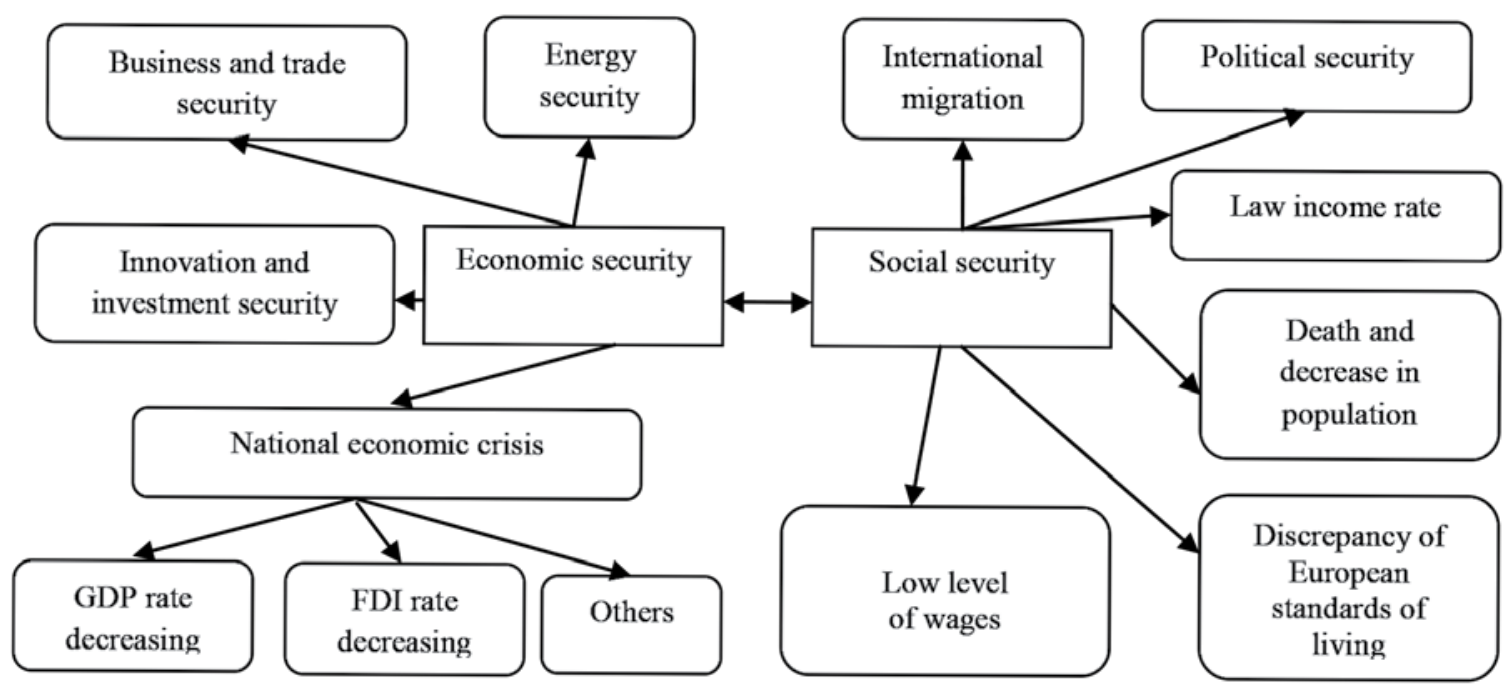

Fig. 3. Scheme of interrelationship of economic and social security at national and European level

Source: author's own work

\section{Main threats and opportunities of economic and social security at national and European level}

The main threats of economic and social security at national and European level are:

energy dependence;

business and trade dimensions;

social challenges that have a number of different problematic aspects (migrants, unemployment, social instability).

International organizations or other global actors to interfere can contribute to the enhancement of the level of national economic security. Effective social and economic efforts should direct to provide conditions for increasing of international trade, foreign direct investments in national economy and also investments into human capital (Boda et al. 2013).

The strategic factors that directly influence the state of the economic safety of a state include the technological re-equipment of the national economy, saturation of it with highly productive systems of technologies and innovations, as well as with new materials that implement innovative achievements of science and technology (Kudrjavcev, Kudrjavceva 2015).

The opportunities of economic and social security at national level are providing the social economy stands that will have a positive effect on the social and economic development and growth of the country (Figure 4). It's noticeable, that a characteristic feature of the social economy is that the social and economic relations system is determined by the variety of existing forms of ownership, freedom of economic activity, competition, but at the same time it is limited by strong state social policy. This politics is based on the principle of ensuring a high standard of living; guarantees of social protection, high level of national economy development. Except the social economy development, the opportunities of social and economic security at national level are: new energy strategy and policy, intellectual elites and middle class collaboration and non-political tools (students, culture and environment).

Of course, all mentioned above will positively affect the social and economic development of country. 


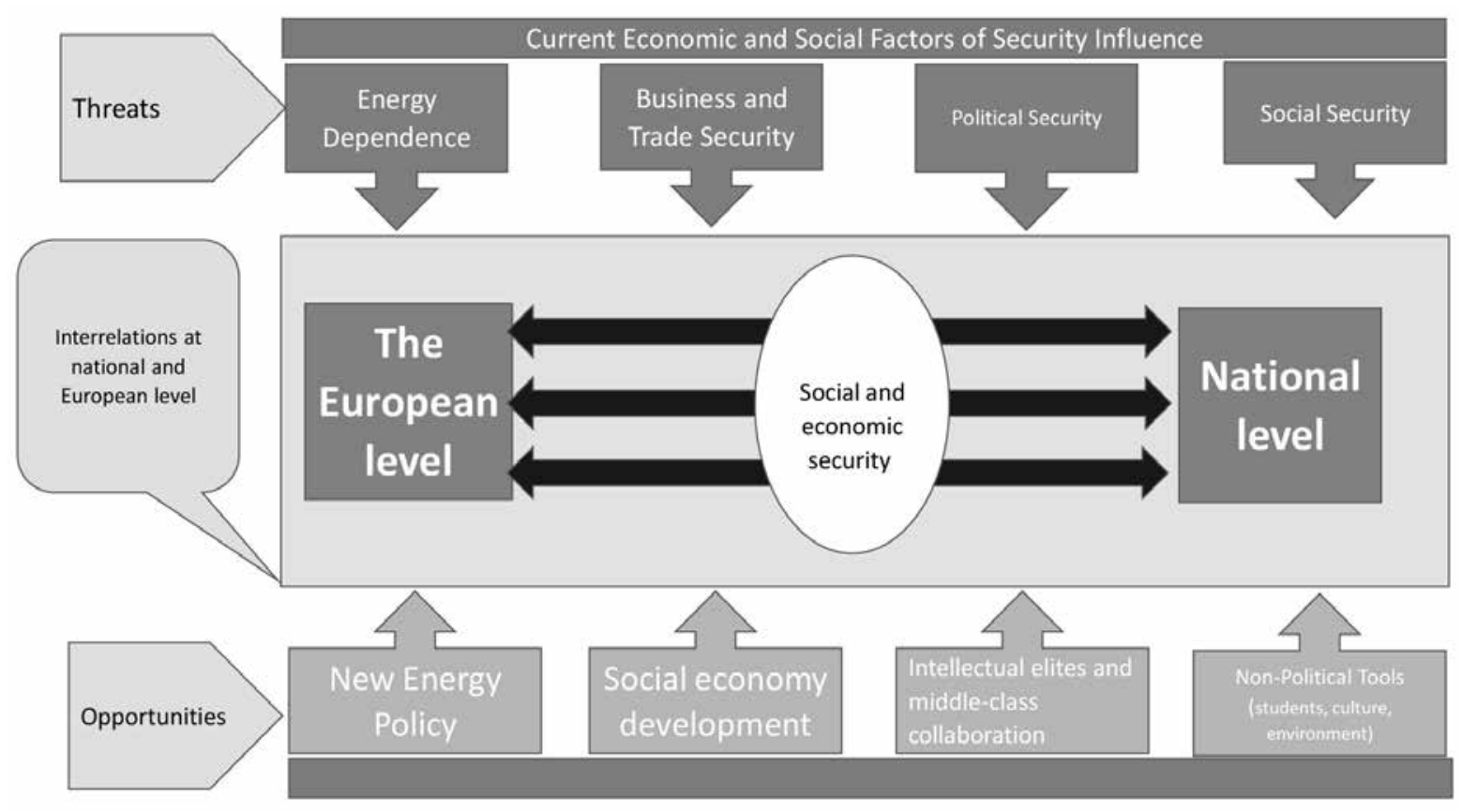

Fig. 4. Scheme of main threats and opportunities of economic and social security at national and European level

Source: author's own

\section{Conclusions}

Ukrainian geopolitical choice is European integration that shows solidarity with European values and principles. Ukraine confirms its willingness to move towards European integration and to become a part of European Union.

This research shows the interrelationships of economic and social security at national and European level. So, Ukrainian crisis brings not only economic problems, but also a lot of social challenges, as people's death, international emigration, crimes growth, unemployment growth, negative impact on civil society and social development of Ukraine.

Nowadays we need to develop integrated constructive and pragmatic approach to ensure safety in Ukraine and Europe.

\section{References}

Abramov, V.; Moshinskij, R. 2011. Theory of Security and Institutions (on the choice of methodological basis for the scientific research of the system of national security). Bulletin of the National Academy of Public Administration under the President of Ukraine, 3: 5-13 (in Ukrainian).

Ball, N. 2014. Security and Economy in the Third World (Princeton Legacy Library), Princeton University Press

Bates, R. 2017. The Development Dilemma: Security, Prosperity, and a Return to History. Princeton University Press

Boda, G.; Stukalo, N.; Stolyarchuk, Y.; József, F. 2013. Intellectual Capital Paradox: The case of Hungary and Ukraine. Journal of Developing Countries Studies. 3 (8), 64-81. Available at: http://unipub.lib.uni-corvinus.hu/2014/1/intellectual_capital_paradox_u.pdf

Brożyna, J.; Mentel, G.; Szetela, B.; Strielkowski, W. 2018. Multi-seasonality in the TBATS model using demand for electric energy as a case study, Economic Computation \& Economic Cybernetics Studies \& Research 52(1):229-246. https://doi.org/10.24818/184232 $64 / 52.1 .18 .14$

Čábelková, I.; Abrhám, J.; Strielkowski, W. 2015. Factors influencing job satisfaction in post-transition economies: the case of the Czech Republic. International Journal of Occupational Safety and Ergonomics 21(4):448-456. https://doi.org/10.1080/10803548.201 


\subsection{7}

Collier, P. 2007 'Economic Causes of Civil Conflict and Their Implications for Policy'. In Leashing the Dogs of War: Conflict Management in a Divided World, ed. Crocker, Hampson and Aall. United States Institute of Peace Press, Washington, D.C.

Common Foreign and Security Policy (CFSP), 2009, Available at: https://eeas.europa.eu/printpdf/420_en

Dyson, T., 2008. The Politics of German Defence and Security: Policy Leadership and Military Reform in the post-Cold War Era. Oxford, New York : Independent Publishing Berghahn Books.

Eurostat, 2016. 'First time asylum applicants in the EU'. Available at: http://ec.europa.eu/eurostat/statistics-explained/index.php/ File:First_time_asylum_applicants_in_the_EU28_by_citizenship,_Q4_2015_\%E2\%80\%93_Q4_2016.png

Eurostat, 2017. 'International trade in goods' Available at: http://ec.europa.eu/eurostat/data/database

Eurostat, 2017. 'Migration and migrant population statistics' Available at: http://ec.europa.eu/eurostat/statistics-explained/index.php/ Migration_and_migrant_population_statistics

Eurostat, 2017. EU imports of energy products - recent developments. Available at: http://ec.europa.eu/eurostat/statistics-explained/ index.php/EU_imports_of_energy_products_-_recent_developments

Fakhry, B.; Aktan, B.; Masood, O.; Tvaronavičienė, M.; Celik, S. 2018. The Impact Of A Recent Natural Disaster On The Japanese Financial Markets: Empirical Evidenece, Journal of Competitiveness 10(2): 56-71 https://doi.org/10.7441/joc.2018.02.04

Gas in focus, 2017. Imports of natural gas in the EU-28, 2017 Available at: www.gasinfocus.com

Hacker, J. 2006. The Great Risk Shift: The New Economic Insecurity and the Decline of the American Dream, Oxford University Press

Kassab, H., 2015. Weak States in International Relations Theory: The Cases of Armenia, St. Kitts and Nevis, Lebanon, and Cambodia

Komarova, V.; Lonska, J.; Lavrinenko, O.; Menshikov, V. 2018. Influence of existing social and economic interactions on sustainable territory development: the case of Iceland, Entrepreneurship and Sustainability Issues 5(3): 412-437. https://oi.org/10.9770/ jesi.2018.5.3(1)

Kozlovskyi S.; Khadzhynov I.; Vlasenko I.; Marynchak, L. 2017. Managing the sustainability of economic system as the basis of investment development in Ukraine. Investment Management and Financial Innovations (open-access), 14(4), 50-59. https://doi. org/10.21511/imfi.14(4).2017.06

Kriviņš, A. 2015. Towards security and safety: police efficiency across European countries, Journal of Security and Sustainability Issues 5(1): 35-44. https://doi.org/10.9770/jssi.2015.5.1(3)

Kudrjavcev, V. M.; Kudrjavceva, O. V. 2015. Stages of investment development of branches of the national economy and main state measures on regulation of investment security, Economy. Finances. Law, 8(2), pp. 49-52 (in Ukrainian).

Kuril, J. 2018. Public administration for safe and secure environment: case of Slovak Republic, Entrepreneurship and Sustainability Issues5(3): 493-501. https://doi.org/10.9770/jesi.2018.5.3(6)

Lankauskienè, T.; Tvaronavičienè, M. 2012. Security and sustainable development approaches and dimensions inn the globalization context, Journal of Security and Sustainability Issues 1(4): 287-297. https://doi.org/10.9770/jssi.2012.1.4(5)

Leal-Arcas, R.; Rios, J. A.; Grasso, C., 2015. 'The European Union and its energy security challenges: engagement through and with networks', Contemporary Politics, 21(3), 273-293. https://doi.org/10.1080/13569775.2015.1061242

Limba, T.; Šidlauskas, A. 2018. Secure personal data administration in the social networks: the case of voluntary sharing of personal data on the Facebook, Entrepreneurship and Sustainability Issues 5(3): 528-541. https://doi.org/10.9770/jesi.2018.5.3(9)

Makštutis, A.; Balkytė, A.; Tumalavičius, V. 2012. Security, Sustainability and Competitiveness: Benchmarking attempts, Journal of Security and Sustainability Issues 2(1): 5-12. https://doi.org/10.9770/jssi/2012.2.1(1)

Marks, G., \&Steenbergen, M. R. 2004. European integration and political conflict. Cambridge University Press. https://doi.org/10.1017/ CBO9780511492013

Menshikov, V.; Volkova, O.; Stukalo, N.; Simakhova, A. 2017. Social economy as a tool to ensure national security, Journal of Security and Sustainability Issues 7(2): 31-51. https://doi.org/10.9770/jssi.2017.7.2(4) 
Načisčionis, J.; Skrastin̦a, U.; Tumalavičius, V. 2018. Secure development of public administration, Journal of Security and Sustainability Issues 8(1): 87-102. https://doi.org/10.9770/jssi.2018.8.1(8)

N̦esterova, M.; Teivāns-Treinovskis, J.; Ivančiks, J. 2015. Security and public safety: impact of gender on prisoners' justice perception, Journal of Security and Sustainability Issues 4(4): 403-413. https://doi.org/10.9770/jssi.2015.4.4(7)

Prontera, A., 2017. 'Forms of state and European energy security: diplomacy and pipelines in Southeastern Europe', European Security, 26(2), 273-298. https://doi.org/10.1080/09662839.2017.1313233

Radwan, A. 2018. Science and innovation policies in North African Countries: Exploring challenges and opportunities, Entrepreneurship and Sustainability Issues 6(1): 268-282. https://doi.org/10.9770/jesi.2018.6.1(17)

Simakhova, A. O., 2016. 'Analysis of the foreign economic factors impact on the welfare of Ukrainians in the conditions of the world integration processes'. Marketing and Management of Innovations, 3, 263-271.

Smirnov, A.; Lavrinenko, O.; Tumalavičius, V. 2018. Analysis of social-economic security of administrative areas in latvian municipalities, Journal of Security and Sustainability Issues 7(4): 817-829. DOI: http://doi.org/10.9770/jssi.2018.7.4(17)

Stańczyk, J. 2011. European security and sustainability issues in the context of current international environment, Journal of Security and Sustainability Issues 1(2): 81-90. https://doi.org/10.9770/jssi.2011.1.2(1)

State Statistics Service of Ukraine, 2016. 'Social and Economic Development of Ukraine in 2016'. Available at: http://www.ukrstat. gov.ua/

State Statistics Service of Ukraine, 2017. 'Social and Economic Development of Ukraine in 2017'. Available at: http://www.ukrstat. gov.ua/

Steblianko I. O., Doroshkevych V. I. 2017. Innovative-investment mechanisms of regulation of economic security of the state. European Journal of Management Issues, 25 (3- 4), p. 154-161. https://doi.org/10.15421/191719

Stukalo, N., Simakhova A. 2018. Social and economic effects of the war conflict in Ukraine for Europe. Geopolitics under Globalization, 2(1), 11-18 https://doi.org/10.21511/gg.02(1).2018.02

Stukalo, N., Simakhova, A. 2018. Global parameters of social economy clustering. Problems and Perspectives in Management, 16(1), 36-47. https://doi.org/10.21511/ppm.16(1).2018.04

Teivāns-Treinovskis, J.; Jefimovs, N. 2012. State national security: aspect of recorded crime, Journal of Security and Sustainability Issues 2(2): 41-48. DOI: http://dx.doi.org/10.9770/jssi.2012.2.2(4)

Tireuov, K.; Mizanbekova, S.; Kalykova, B.; Nurmanbekova, G. 2018. Towards food security and sustainable development through enhancing efficiency of grain industry, Entrepreneurship and Sustainability Issues6(1): 446-455. https://doi.org/10.9770/jesi.2018.6.1(27)

Todorov, G. N.; Kalinina, A. V.; Rybakova, A. I. 2018. Impact of labour migration on entrepreneurship ecosystem: case of Eurasian Economic Union, Entrepreneurship and Sustainability Issues 5(4): 992-1007. https://doi.org/10.9770/jesi.2018.5.4(20)

Trofimovs, I.; Ivančiks, J. 2017. National security strengthening through the operational activities law, Journal of Security and Sustainability Issues 6(3): 391-400. https://doi.org/10.9770/jssi.2017.6.3(6)

Tumalavičius, V. 2016. Security of Society in Lithuania: Concept and Scientific Fundamentals in its Ensuring. Sociālo Zinātņu Vēstnesis. 2016, 1(22): 92-118 pp. Daugavpils Universitāte, Humanitāro un sociālo zinātṇu institūts. ISSN 1691-1881.

Tumalavičius, V. 2017. Viešojo saugumo užtikrinimo teisiniai aspektai Lietuvoje: dabarties tendencijos ir procesai. Mokslo studija [Legal Aspects of Public Security Ensuring in Lithuania. Research Study]. Vilnius: The General Jonas Žemaitis Military Academy of Lithuania. - 219 p.; ISBN 978-609-8074-71-0.

Tvaronavičienė, M. 2018. Toward efficient policy making: forecasts of vulnerability to external global threats, Journal of Security and Sustainability Issues 7(3): 591-600. https://doi.org/10.9770/jssi.2018.7.3(18)

Tvaronavičienė, M.; Nesterova, K.; Kováčik, V. 2017. Energy security and long-term energy efficiency: case of selected counties, Journal of Security and Sustainability Issues 7(2): 349-357. https://doi.org/10.9770/jssi.2017.7.2(14)

Volchik, V.; Klimenko, L.; Posukhova, O. 2018. Socio-economic sustainable development and the precariat: a case study of three Russian cities, Entrepreneurship and Sustainability Issues 6(1): 411-428. https://doi.org/10.9770/jesi.2018.6.1(25)

Zahars, V.; Stivrenieks, M. 2018. Security, surveillance and re-socialization aspects in center for drug addicts of Olaine city prison in 
JOURNAL OF SECURITY AND SUSTAINABILITY ISSUES

ISSN 2029-7017 print/ISSN 2029-7025 online

Latvia, Journal of Security and Sustainability Issues 7(4): 643-656. https://doi.org/10.9770/jssi.2018.7.4(3)

About contributors:

Nataliia STUKALO

ORCID ID: https://orcid.org/0000-0003-0517-1653

Iryna STEBLIANKO

ORCID ID: https://orcid.org/0000-0001-8103-1404

Anastasiia SIMAKHOVA

ORCID ID: https://orcid.org/0000-0001-7553-4531

\section{Vadym DOROSHKEVYCH}

ORCID ID: https://orcid.org/0000-0003-1529-4155 